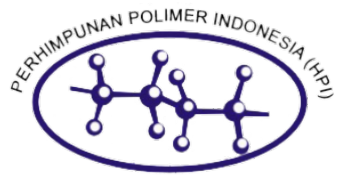

\title{
Pengaruh Hidrolisis dengan Asam Klorida terhadap Karakteristik Polimer Selulosa Mikrokristal dari Alga Hijau (Cladophora sp.)
}

\author{
I G. N. Jemmy Anton Prasetia ${ }^{a}$, Shelia Deviana ${ }^{a}$, Trisna Damayantia, Angga Cahyadia, I M. Agus
} Gelgel Wirasutaa

\begin{abstract}
Cladophora sp. tergolong kedalam spesies alga hijau dengan kandungan selulosa sebanyak 51,61\%. Cladophora sp. dapat menjadi alternatif sumber bahan baku pembuatan selulosa mikrokristal (SM) yang bermanfaat sebagai bahan pembantu dalam formulasi sediaan farmasi. Isolasi selulosa dalam alga Cladophora sp. dilakukan dalam dua tahapan yaitu tahap pertama delignifikasi dengan $\mathrm{NaOH} 0,5 \mathrm{M}$ selama 24 jam pada suhu $60^{\circ} \mathrm{C}$. Proses ini bertujuan untuk memisahkan selulosa dari senyawa lainnya seperti lignin, karbohidrat, asam organik dan resin. Adanya senyawa ini dapat menghambat penetrasi asam sebelum dilakukan proses hidrolisis. Tahap kedua adalah hidrolisis dengan menggunakan asam klorida ( $\mathrm{HCl}$ ). Proses ini bertujuan untuk memutuskan ikatan glikosida yang terdapat dalam selulosa sehingga terjadi pemurnian selulosa. Hal ini akan berdampak terhadap karakteristik dari SM yang dihasilkan. Tujuan penelitian ini adalah untuk mengetahui pengaruh hidrolisis dengan larutan $\mathrm{HCl}$ pada berbagai konsentrasi $(2,5 ; 5,0$ dan 7,5\%) terhadap karakteristik SM dari Cladophora sp. (SMC). Pengujian karakteristik SMC meliputi uji kandungan selulosa alfa, beta dan gamma; uji sifat farmasetik serta uji SEM dan XRD. Berdasarkan pengujian diperoleh hasil bahwa uji sifat farmasetik selulosa mikrokristal sudah memenuhi persyaratan sesuai pustaka. Variasi konsentrasi $\mathrm{HCl}$ memberikan pengaruh terhadap kandungan selulosa alfa, beta dan gamma.
\end{abstract}

Cladophora sp. classified into green algae species with a cellulose content of $51.61 \%$. Cladophora sp. can be an alternative resource of raw material for microcrystalline cellulose (SM), which is useful as an excipient in pharmaceutical formulations. Isolation of cellulose in the algae Cladophora sp. carried out in two stages, the first stage namely delignification with $0.5 \mathrm{M} \mathrm{NaOH}$ for 24 hours at $60^{\circ} \mathrm{C}$. This process aims to separate cellulose from other compounds such as lignin, carbohydrates, organic acids, and resins. The presence of these compounds can inhibit acid penetration before the hydrolysis process. The second stage is hydrolysis using hydrochloric acid $(\mathrm{HCl})$. This process aims to break the issue of cellulose purification. This will have an impact on the characteristics of the SM. The purpose of this study was to

Received

10 October 2018

Received in revised form

Accepted

28 December 2018

Published

31 December 2018

DOI: $10.37889 / \mathrm{mpi} .2018 .21 .2 .2$ determine the effect of hydrolysis with $\mathrm{HCl}$ solutions at various concentrations $(2.5 ; 5.0$; and $7.5 \%)$ on the characteristics of SM from Cladophora sp. (SMC). The characteristics of the SMC include the content of alpha, beta, and gamma cellulose; the pharmaceutical properties; also SEM and XRD. Based on the results of the pharmaceutical properties, SCM has met the requirements according to the literature. The variation of $\mathrm{HCl}$ concentration has an effect on the content of alpha, beta, and gamma cellulose.

Kata kunci: Asam klorida, Cladophora sp., hidrolisis, selulosa mikrokristal.

\section{Pendahuluan}

Indonesia memiliki keanekaragaman hayati bahari yang melimpah. Salah satunya adalah Cladophora sp. Tanaman ini banyak ditemukan di perairan laut, khususnya di daerah Jimbaran, Bali. Tanaman ini tergolong ke dalam spesies alga hijau. Pertumbuhan alga yang tidak terkendali dalam ekosistem air dapat menyebabkan blooming algae.

Alga Cladophora sp. mengandung selulosa sebanyak 51,61\%. Hal ini menyebabkan alga berpotensi menjadi sumber selulosa mikrokristal terbarukan. Selulosa mikrokristal dari alga Cladophora sp. memiliki derajat kristalinitas tinggi dan luas permukaan yang

\footnotetext{
a. Program Studi Farmasi, Fakultas MIPA - Universitas Udayana, Jimbaran, Badung - Bali, 80361, Indonesia

+ Corresponding author: jemmy_anton@unud.ac.id.
}

lebih besar dibandingkan dengan mikrokristalin selulosa dari tanaman berkayu. ${ }^{1}$

Metode isolasi senyawa selulosa pada Cladophora sp. dilakukan dengan metode hidrolisis asam. Salah satu pelarut asam yang digunakan adalah larutan $\mathrm{HCl}$. Konsentrasi $\mathrm{HCl}$ berpengaruh terhadap besarnya rendemen selulosa mikrokristal (SM) yang diperoleh. $^{2}$

Edison dkk. (2015) menghidrolisis ampas tebu menggunakan $\mathrm{HCl} 1,5 \mathrm{~N}$. Penelitian dengan bahan baku nata de coco menunjukkan bahwa penggunaan $\mathrm{HCl} 1 \mathrm{~N}$ telah mampu menghasilkan selulosa mikrokristal dengan rendemen 72,43\%. Prasetia dkk. (2015) menggunakan $\mathrm{HCl}$ 2,5 N untuk menghidrolisis jerami padi varietas Mansur. Sedangkan untuk padi varietas IR64, digunakan $\mathrm{HCl}$ 3,5 N sebagai larutan penghidrolisis terbaik. ${ }^{3-6}$

Oleh sebab itu, perlu dilakukan penelitian mengenai pengaruh konsentrasi $\mathrm{HCl}$ dalam proses hidrolisis terhadap karakteristik selulosa mikrokristal Cladophora sp. (SMC) yang diperoleh dari perairan 
di Jimbaran-Bali. SMC kemudian diuji kandungan selulosa alfa, beta dan gamma; uji sifat farmasetik serta uji SEM dan XRD. Uji sifat farmasetik meliputi organoleptis, laju alir dan indeks Carr. Data dianalisa secara statistik dengan metode ANOVA One Way dengan taraf kepercayaan $95 \%$.

\section{Metode Percobaan}

\section{Alat dan Bahan}

Alga Cladophora $s p$. yang digunakan dalam penelitian berasal dari pantai kawasan Jimbaran-Bali. Akuades (Waterone), $\mathrm{NaOH}$ p.a (Merck), kalium dikromat (Merck), indikator ferroin (Merck), ferro aluminium sulfat (Merck) dan $\mathrm{H}_{2} \mathrm{SO}_{4}$ p.a (Merck).

Peralatan yang digunakan dalam penelitian ini meliputi moister analyzer (MOC 63U Shimadzu) untuk mengetahui kelembaban, tap density tester (ETD-1020 Electrolab) untuk uji bobot jenis, agitator (Labnet) untuk pengadukan, Scanning Electron Microscope (SEM) (Jeol JSM-6510LA) untuk mengamati karakter fisik sediaan dan $X$ Ray Diffraction (XRD) (X'pert PRO PANalytical) untuk menganalisa struktur kristal.

\section{Cara Kerja}

\section{Penyiapan Sampel}

Sampel alga hijau Cladophora sp. dikumpulkan dari perairan pantai Jimbaran - Bali. Kriteria alga yang digunakan adalah berwarna hijau terang dengan panjang sekitar $8-20 \mathrm{~cm}$. Alga kemudian disortasi dan demineralisasi untuk dapat dikeringkan dengan oven pada suhu $60{ }^{\circ} \mathrm{C}$ selama 24 jam.

\section{Isolasi Cladophora sp.}

Proses isolasi terdiri atas delignifikasi dan hidrolisis. Delignifikasi dilakukan dengan merendam 1 bagian sampel dalam 12 bagian $\mathrm{NaOH} 0,5 \mathrm{M}$ di dalam waterbath suhu $60{ }^{\circ} \mathrm{C}$ selama 24 jam. Sedangkan proses hidrolisis dilakukan dengan merendam 1 bagian pulp dalam 20 bagian $\mathrm{HCl}$ pada berbagai konsentrasi. Setelah itu, dilakukan pengeringan dengan oven bersuhu $60^{\circ} \mathrm{C}$ selama 24 jam. Selanjutnya diayak dengan mesh 60 hingga terbentuk SMC.

Tabel 1. Konsentrasi $\mathrm{HCl}$ pada berbagai formula

\begin{tabular}{ccc}
\hline No. & Formula & Konsentrasi $\mathrm{HCl}$ (\%) \\
\hline 1 & SMC-1 & 2,5 \\
2 & SMC-2 & 5,0 \\
3 & SMC-3 & 7,5 \\
\hline
\end{tabular}

\section{Evaluasi Selulosa Mikrokristal Cladophora sp.}

Uji kandungan selulosa alfa, beta dan gamma dilakukan sesuai dengan prosedur SNI tahun 2009 tentang Cara Uji Kadar Selulosa Alfa, Beta dan Gamma. ${ }^{7}$ Sedangkan sifat farmasetik dianalisa dari hasil pengujian organoleptis, laju alir dan indeks Carr. Karakterisasi SMC diidentifikasi dengan Scanning Electron Microscope (SEM) dan $X$-Ray Diffraction (XRD).

\section{Hasil dan Pembahasan}

Kandungan (\%) selulosa alfa, beta dan gamma dari formula SMC-1, SMC-2 dan SMC-3 berturut-turut adalah 93,43 $\pm 0,49 ; 95,33 \pm 0,37$; $96,67 \pm 0,26$ dan $3,32 \pm 0,41 ; 2,46 \pm 0,34 ; 1,74 \pm 0,41$ serta $3,25 \pm 0,08$; $2,21 \pm 0,04 ; 1,57 \pm 0,21$ (Gambar 1). Hal ini menunjukkan bahwa semakin tinggi konsentrasi $\mathrm{HCl}$ yang digunakan maka kadar selulosa alfa yang diperoleh semakin banyak serta kadar selulosa beta dan gamma semakin menurun. Proses hidrolisis menyebabkan terjadinya penarikan bagian kristalin dari selulosa. ${ }^{8} \mathrm{Hal}$ ini menyebabkan kandungan selulosa alfa meningkat seiring dengan peningkatan konsentrasi $\mathrm{HCl}$ yang digunakan. Semakin tinggi konsentrasi asam maka semakin banyak kesempatan $\mathrm{HCl}$ untuk mengisolasi daerah kristalin dari selulosa sehingga tingkat kemurnian dari selulosa mikrokristal semakin meningkat.

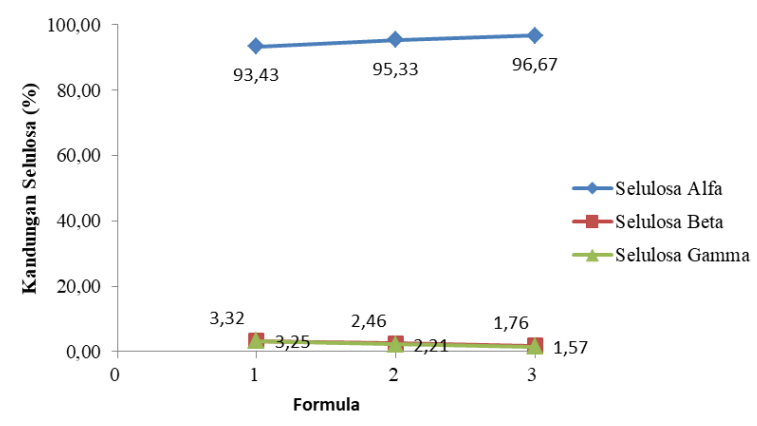

Gambar 1. Kurva kandungan selulosa (\%) pada masing-masing formula SMC.

Berdasarkan hasil uji statistik dengan metode Anova One Way menunjukkan bahwa konsentrasi $\mathrm{HCl}$ berpengaruh signifikan terhadap kandungan selulosa alfa dan gamma. Namun, pada SMC-1 dan SMC-2, kandungan beta menunjukkan hasil yang tidak berbeda bermakna.

Mikrokristalin selulosa yang dihasilkan dari alga hijau Cladophora $s p$. memiliki organoleptis berupa serbuk berwarna hijau pekat dan tidak terdapat bau khas lautan (Tabel 2). Hasil yang sama ditemukan pada semua formula. Hal ini menunjukkan bahwa perlakuan yang diberikan tidak memberikan dampak perubahan organoleptis pada SMC.

Tabel 2. Hasil uji farmasetik dari masing-masing formula SMC

\begin{tabular}{cccc}
\hline Uji & \multicolumn{3}{c}{ Hasil } \\
\cline { 2 - 4 } Farmasetik & SMC-1 & SMC-2 & SMC-3 \\
\hline Organoleptis & $\begin{array}{c}\text { Serbuk berwarna Serbuk berwarna } \\
\text { hijau pekat dan } \\
\text { tidak berbau }\end{array}$ & $\begin{array}{c}\text { hijau pekat dan } \\
\text { tidak berbau }\end{array}$ & $\begin{array}{c}\text { hijau pekat dan } \\
\text { tidak berbau }\end{array}$ \\
$\begin{array}{c}\text { Laju Alir } \\
\text { (g s }\end{array}$ \\
$\begin{array}{c}\text { Indeks Carr } \\
\text { (\%) }\end{array}$ & $5,34 \pm 0,56$ & $6,40 \pm 0,35$ & $6,37 \pm 0,54$ \\
\hline
\end{tabular}

Serbuk SMC-1, SMC-2 dan SMC-3 memiliki laju alir dan indeks Carr berturut-turut adalah 5,34 $\pm 0,56 ; 6,40 \pm 0,35 ; 6,37 \pm 0,54\left(\mathrm{~g} \mathrm{~s}^{-1}\right)$ dan $13,59 \pm 0,23 ; 14,27 \pm 0,72 ; 14,42 \pm 0,63 \%$ (Tabel 2). Berdasarkan 
laju alir, selulosa mikrokristal dari semua formula memiliki sifat alir yang baik. Laju alir dipengaruhi oleh kristalinitas suatu bahan. Semakin tinggi konsentrasi $\mathrm{HCl}$ yang digunakan untuk proses hidrolisis akan menghasilkan sifat kristalinitas yang lebih tinggi. Hal ini karena terjadi penurunan jumlah gugus amorf. ${ }^{3}$ Berdasarkan uji statistik dengan metode Anova One Way, tidak terdapat perbedaan signifikan terhadap variasi konsentrasi $\mathrm{HCl}$ yang digunakan pada proses hidrolisis.

Indeks Carr merupakan kemampuan kompresibilitas dari suatu serbuk yang menunjukkan sifat alirannya. Serbuk yang semakin mudah mengalir maka kemampuan kompresibilitasnya akan meningkat. Hal ini menjadi faktor utama yang diperhatikan dalam pemilihan eksipien pada formulasi sediaan tablet. Indeks Carr dibawah $15 \%$ menunjukkan bahwa bahan tersebut memiliki aliran yang baik. ${ }^{9}$ Dari keseluruhan formula, diperoleh indeks Carr dibawah 15\% (Tabel 2). Berdasarkan uji statistik dengan metode Anova One Way, data tersebut tidak berbeda signifikan.

$X$-Ray Diffraction (XRD) digunakan untuk memberikan informasi tentang struktur kristalografi dari suatu material. Selain itu, XRD juga digunakan untuk mengamati sifat kristalinitas suatu material berdasarkan pada susunan struktur atomnya. ${ }^{8}$ Selulosa tersusun dari daerah kristalin dan daerah amorf. Daerah kristalin mengandung lignin dan hemiselulosa. Daerah kristalin ditunjukkan oleh sudut $2 \theta$ sebesar $21-24^{\circ}$ sedangkan daerah amorf ditunjukkan oleh sudut $2 \theta 15^{\circ} .{ }^{10-11}$

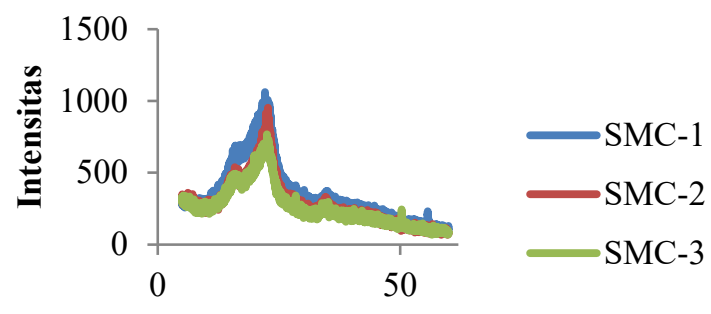

Sudut $2 \theta$

Gambar 2. Spektrum hasil XRD pada masing-masing formula SMC.

Hasil XRD pada SMC-1, SMC-2 dan SMC-3 masih terdapat puncak pada sudut $15^{\circ}$ (Gambar 2). Hal ini mengindikasikan bahwa proses hidrolisis belum dapat menghilangkan seluruh bagian amorf dan mengisolasi semua bagian kristalin yang ada pada selulosa. ${ }^{12}$

Uji SEM dapat dilihat pada Gambar 3. Berdasarkan hasil yang diperoleh, SMC pada berbagai formula menggambarkan adanya serat-serat fibril seperti penelitian sebelumnya. ${ }^{2}$ Serat fibril tersebut berkaitan dengan laju alirnya. Semakin banyak serat yang terkandung maka semakin susah uap air untuk terpenetrasi. Hal ini menyebabkan kelembaban SMC semakin rendah sehingga partikelpartikel dalam SMC tersebut akan semakin terpisah. Dengan demikian, laju alir yang dimiliki akan semakin meningkat.

Kristalinitas yang tinggi menyebabkan air tidak mudah terpenetrasi melalui serat-serat fibril sehingga mikrokristalin selulosa yang dihasilkan memiliki kelembapan yang rendah. Kelembapan yang rendah akan berefek pada laju alir dari mikrokristalin selulosa. Dengan demikian, mikrokristalin dengan kelembapan yang rendah mengandung sedikit air sehingga akan mempermudah mikrokristalin selulosa untuk mengalir. ${ }^{2}$

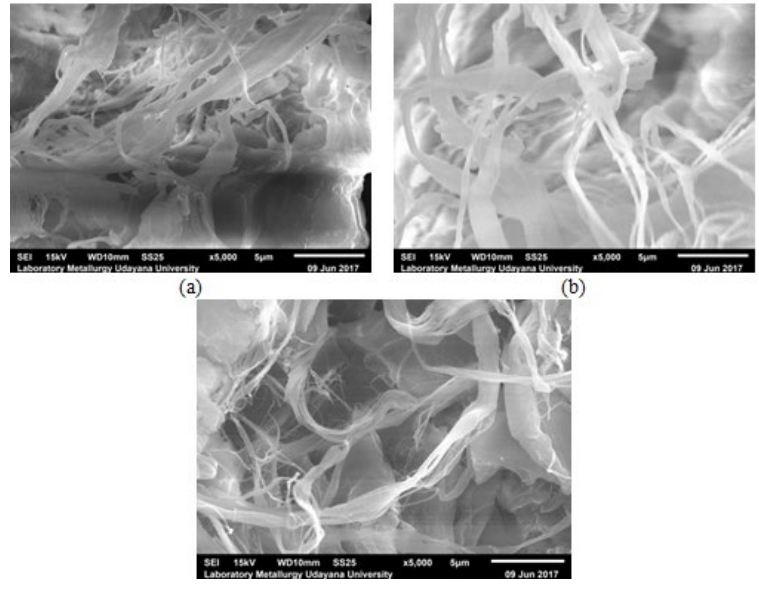

Gambar 3. Hasil Scanning Electron Microscope (SEM) dengan pembesaran 5000 kali pada masing-masing formula SMC. (A : SMC-1; B : SMC-2 dan C : SMC-3).

\section{Kesimpulan}

Variasi konsentrasi $\mathrm{HCl}$ pada proses hidrolisis memberikan pengaruh terhadap kandungan selulosa alfa, beta dan gamma dari selulosa mikrokristal Cladophora sp. Namun, hal ini tidak ditemukan pada pengujian farmasetis, XRD dan SEM. Pada pengujian tersebut, diperoleh hasil yang tidak berbeda signifikan. Penggunaan $\mathrm{HCl} 7,5 \%$ (SMC-3) menghasilkan selulosa mikrokristal terbaik karena kandungan selulosa alfa terbesar sehingga kemurniannya tertinggi.

\section{Ucapan Terima Kasih}

Penulis mengucapkan terima kasih kepada Lembaga Penelitian dan Pengabdian Masyarakat (LPPM) Universitas Udayana yang telah memberikan bantuan dana penelitian.

\section{Referensi}

1 D.H. Camacho, J.P.C. Gerongay dan Macalinao, CladophoraceIlulose-polyaniline composite for remediation of toxic chromium (VI), Cell. Chem. Technol., 2013, 47, 125-132.

2 A. Mihranyan, S. Andersson dan R. Ek, Sorption of Nicotine to Cellulosa Powders, European Journal of Pharmaceutical Sciences, 2004, 22, 297-286.

3 D. Edison, Neswati dan I.D. Rahmi, Pengaruh Konsentrasi $\mathrm{HCl}$ dalam Proses Hidrolisis $\alpha$-Selulosa dari Ampas Tebu (Saccharum officinarum L.) terhadap Karakteristik Mikrokristalin, Tesis Magister, Universitas Andalas, Padang, 2015.

4 N.S. Pane, Pengaruh Konsentrasi HCl pada Hidrolisis Limbah Padat Nata de Coco Terhadap Karakteristik Mikrokristalin Selulosa, Skripsi Sarjana, Universitas Andalas, Padang, 2014.

5 I G.N.J.A. Prasetia, I G.N.A.D. Putra, D.A.M.I.P.S. Arsana, dan N.P.M. Prabayanti, Studi Karakteristik Farmasetis Mikrokristalin Selulosa dari Jerami Padi Varietas Lokal Bali, Jurnal Sains Materi Indonesia, 2015, 17(3), 119-123. 
6 I G.N.J.A. Prasetia, I D.A. Yuliandari, D.G. Ulandari, C.I.S. Arisanti dan A.A.I.S.H. Dewandari, Evaluasi Kandungan Selulosa Mikrokristal Dari Jerami Padi (Oryza sativa L.) Varietas IR64, Jurnal Kimia, 2018, 12(2), 1-5.

7 SNI, Pulp-Cara Uji Kadar Selulosa Alfa, Beta dan Gamma, Jakarta: Badan Standarisasi Nasional, 2009.

8 D. Trache, M.H. Hussin, C.T.H. Chuin, S. Sabar, M.R.N. Fazita, O.F.A. Taiwo, T.M. Hassan dan M.K.M. Haafiz, Microcrystalline Cellulose: Isolation, Characterization and Bio-composites Application - A Review, International Journal of Biological Macromolecules, 2016, 93(A), December 2016, 789-804.
9 L. Lachman, H.A. Lieberman dan J.L. Kanig, Teori dan Praktik Farmasi Industri. 3rd Edition. Penerjemah: Siti Suyatni, Jakarta: UIPress, 2008.

10 J.Q. Wan, Y. Wang, Q. Xiao, Effect of Hemicelullose Removal on Cellulose Fiber Strucure and Recycling Characteristics of Eucalyptus Pulp, Biores. Technol.,2010, 101, 4577-4583.

11 M. Jonoobi, J. Harun, A. Shakeri, M. Misra, K. Oksman, Chemical Composition, Crystallinity, and Thermal Degradation of Bleached and Unbleached Kenaf Bast (Hibiscus cannabinus), Bio Resources, 2009, 4(2), 626-639.

12 I. Risnasari, F. Febrianto, N.J. Wistara, S. Sadiyo dan S. Nimatin, Morfologi Mikrofibril Selulosa dari Sludge Primer, Jurnal IImu dan Teknologi Kayu Tropis, 2013, 11(2), 177-183. 